\title{
The Relationship between Life Satisfaction and Academic Performance: An Example of Sports Science
}

\author{
Çağdaş $\mathrm{Caz}^{1, *}$ \& Levent Tanyeri \\ ${ }^{1}$ School of Physical Education and Sport, Yozgat Bozok University, Yozgat, Turkey \\ ${ }^{2}$ School of Sarıkamış Physical Education and Sport, Kafkas University, Kars, Turkey \\ *Correspondence: School of Physical Education and Sport, Yozgat Bozok University, Yozgat, Turkey. E-mail: \\ cazcagdas@gmail.com
}

Received: September 4, 2018 Accepted: October 8, 2018 Online Published: October 25, 2018

doi:10.5430/wje.v8n5p192 URL: https://doi.org/10.5430/wje.v8n5p192

\begin{abstract}
Everyday stress, happiness, health status and individual characteristics affect life satisfaction, which, in turn, affect some other factors. Therefore, high life satisfaction in academics affects their academic performance positively. The aim of this study is to examine the relationship between sports science academics' life satisfaction and academic performance. Study sample consisted of 188 male and 151 female sports science academics working in different regions. Data were collected using the "Contentment with Life Assessment Scale" (CLAS) developed by Lavallee, Hatch, Michalos \& McKinley (2007), and adapted to Turkish language by Akın and Yilmaz (2015), and the "Perceived Academic Performance Scale" developed by Gür (2017). Data were analyzed using descriptive statistics, t-test, one-way variance analysis (ANOVA), Tukey multiple comparison test and correlation test. Results show that male academics have better academic performance than female academics. Results show no statistically significant relationship between life satisfaction and academic performance.
\end{abstract}

Keywords: life satisfaction, academic performance, academics, sports sciences

\section{Introduction}

The concept of life satisfaction was first put forward in a series of research conducted by Neugarten. She defines life satisfaction as the outcome obtained by the comparison of one's expectations and what one already possesses (Vara, 1999). Life satisfaction, in other words, is defined as the general evaluation of the quality of life based on one's own chosen criteria (Ülker Tümlü \& Recepoğlu, 2013). Life satisfaction, as a state of mind, refers to the level of positive attainment as a result of one's overall evaluation of the quality of one's own life. Life satisfaction also refers to how content an individual is with his or her life (Veenhoven, 1996). The evaluation of one' life satisfaction, which is essentially a subjective process, refers to the acceptance of one's life circumstances or the fulfillment of one's needs for one's life as a whole (Sousa \& Lyubomirsky, 2001). Life satisfaction is related to many factors. Some of these factors are quality of life (Güllü \& Çiftçi, 2016) and healthy lifestyle behaviors (Kostak, Kurt, Süt, Akarsu \& Ergül, 2014).

Many variables such as age, stress level, physical health status, lifestyle and personality traits play a significant role in life satisfaction (Chow, 2005). It is also stated that social interaction, sexual activity, success, physical activity, nature and occupation, reading, listening to music, nutrition and beverage consumption have a positive effect on life satisfaction (Dockery, 2003). Therefore, high life satisfaction has positive repercussions on many aspects of both personal and work life. These positive repercussions also affect academics' academic performance directly or indirectly.

One of the factors that determines the academic performance of academics is the number of scientific studies that they have published books, articles, reports, projects, scholarships, prizes, achievements in foreign language and science exams, editorship, citations. Academics with high academic performance become productive in a suitable university environment (Okur, 2007). Higher education not only contributes to social development but also has a strategic national role because it is an arena of global competition in the fields of science, technology and economy. A new university model has emerged all over the world as a result of the growing global competition in science and 
technology, and expectations regarding the role of universities in it. This new model plays an important role not only in the production of information but also in the transformation of information into technology and its introduction to the market through sectoral collaborations (Çetinsaya, 2014; Kavak, 2011; Kenan, 2015). In this context, we believe that this study contributes to determine sports science academics' life satisfaction and academic performance and to gain insight into the relationship between the two concepts.

\section{Method}

\subsection{Study Sample}

The study sample consisted of 188 male and 151 female sports science academics working in different universities.

\subsection{Data Collection}

Data were collected using the "Contentment with Life Assessment Scale" (CLAS) developed by Lavallee, Hatch, Michalos \& McKinley (2007), and adapted to Turkish language by Akın \& Yllmaz (2015), and the "Perceived Academic Performance Scale" (PAPS) developed by Gür.

CLAS consists of 5 items rated on a 7-point Likert scale (ranging from "strongly disagree $=1$ " to "strongly agree $=$ 7"), with the lowest score being 5 and highest score being 35. Items 3 and 4 are reverse scored. PAPS consists of a total of 26 items (19 positive and 7 negative items) rated on a 5-point Likert scale (ranging from "never = 1" to "always $=5$ ") with the lowest score being 26 and highest score being 130 .

\subsection{Data Collection Process}

Data were collected in two stages. First a questionnaire and then a google online form were used to collect data. The online form was emailed to all participants. Data collection lasted one month and the data were transferred to a computer for analysis.

\subsection{Data Analysis}

Normality test was used to determine whether the data were normally distributed. Tests of normality assumptions showed that the data were normally distributed, and therefore, parametric tests were performed. Table 1 shows the arithmetic mean, standard deviation, minimum-maximum, skewness and kurtosis values. Data were analyzed using the Statistical Package for Social Sciences (SPSS) at a significance level of 0.05.T-test and one-way analysis of variance (ANOVA) were used for independent two groups. Tukey's HSD multiple comparison test was used to determine from which groups the statistical difference in ANOVA originated.

\section{Findings}

Table 1. Scale Score Distribution

\begin{tabular}{llllllll}
\hline Scales & N & Min. & Max. & Mean & SD & Skewness & Kurtosis \\
\hline Foreign Language Self-Efficacy & 339 & 13.00 & 50.00 & 34.71 & 8.60 & -.133 & -.711 \\
Scientific Research Self-Efficacy & 339 & 6.00 & 25.00 & 19.19 & 3.68 & -.520 & -.036 \\
Technology Self-Efficacy & 339 & 11.00 & 25.00 & 20.15 & 2.95 & -.457 & .070 \\
Effective Lecture & 339 & 7.00 & 15.00 & 12.95 & 1.59 & -.631 & .188 \\
Self-Efficacy in the Face of External Factors & 339 & 3.00 & 15.00 & 9.96 & 2.43 & -.195 & -.159 \\
Academic Performance Total & 339 & 54.00 & 127.00 & 3.73 & 14.46 & -.293 & -.129 \\
Life Satisfaction Total & 339 & 5.00 & 35.00 & 3.47 & 6.94 & .145 & -.556 \\
\hline
\end{tabular}

The data were analyzed, and descriptive values (standard deviation, mean, minimum and maximum values) were presented. Normality test was used to determine whether the data were normally distributed. Tests of normality assumptions showed that the data were normally distributed. 
Table 2. T-Test Results of Academic Performance and Life Satisfaction in Terms of Gender

\begin{tabular}{|c|c|c|c|c|c|c|}
\hline Scales & Gender & $\mathbf{N}$ & Mean & SD & $\mathbf{t}$ & $\mathbf{p}$ \\
\hline \multirow[t]{2}{*}{ Foreign Language Self-Efficacy } & Women & 151 & 33.76 & 8.98 & \multirow[t]{2}{*}{-1.844} & \multirow[t]{2}{*}{.066} \\
\hline & Men & 188 & 35.48 & 8.22 & & \\
\hline \multirow[t]{2}{*}{ Scientific Research Self-Efficacy } & Women & 151 & 18.92 & 3.74 & \multirow[t]{2}{*}{-1.229} & \multirow[t]{2}{*}{.220} \\
\hline & Men & 188 & 19.41 & 3.62 & & \\
\hline \multirow[t]{2}{*}{ Technology Self-Efficacy } & Women & 151 & 19.72 & 2.98 & \multirow[t]{2}{*}{-2.412} & \multirow[t]{2}{*}{.016} \\
\hline & Men & 188 & 20.49 & 2.89 & & \\
\hline \multirow[t]{2}{*}{ Effective Lecture } & Women & 151 & 12.99 & 1.61 & \multirow[t]{2}{*}{.390} & \multirow[t]{2}{*}{.697} \\
\hline & Men & 188 & 12.92 & 1.57 & & \\
\hline \multirow[t]{2}{*}{$\begin{array}{l}\text { Self-Efficacy in the Face of } \\
\text { External Factors }\end{array}$} & Women & 151 & 9.801 & 2.32 & \multirow[t]{2}{*}{-1.105} & \multirow[t]{2}{*}{.270} \\
\hline & Men & 188 & 10.09 & 2.52 & & \\
\hline \multirow[t]{2}{*}{ Academic Performance Total } & Women & 151 & 95.19 & 14.91 & \multirow[t]{2}{*}{-2.047} & \multirow[t]{2}{*}{.041} \\
\hline & Men & 188 & 98.42 & 13.97 & & \\
\hline \multirow[t]{2}{*}{ Life Satisfaction Total } & Women & 151 & 16.93 & 6.83 & \multirow[t]{2}{*}{-1.069} & \multirow[t]{2}{*}{.286} \\
\hline & Men & 188 & 17.74 & 7.02 & & \\
\hline
\end{tabular}

T-test results showed no statistically significant difference in life satisfaction scores between male and female participants ( $\mathrm{LSt}=-1.069 / \mathrm{p}>0.05$ ). However, male participants' academic performance total score and technology self-efficacy scores were higher than those of female participants $(\mathrm{p}<0.05)$.

Table 3. Anova Test Results of Mobbing Exposure

\begin{tabular}{|c|c|c|c|c|c|c|c|}
\hline Scales & Mobbing & $\mathbf{N}$ & Mean & SD & $\mathbf{F}$ & $\mathbf{p}$ & Sig. \\
\hline \multirow{4}{*}{$\begin{array}{l}\text { Foreign Language } \\
\text { Self-Efficacy }\end{array}$} & Yes & 143 & 34.47 & 9.24 & & & \\
\hline & No & 96 & 35.51 & 8.47 & .575 & .563 & ----- \\
\hline & Partially & 100 & 34.31 & 7.77 & & & \\
\hline & Yes & 143 & 19.49 & 3.68 & & & \\
\hline \multirow{3}{*}{$\begin{array}{l}\text { Scientific Research } \\
\text { Self-Efficacy }\end{array}$} & No & 96 & 18.88 & 3.82 & .885 & .414 & ----- \\
\hline & Partially & 100 & 19.06 & 3.54 & & & \\
\hline & Yes & 143 & 20.26 & 3.12 & & & \\
\hline \multirow[t]{3}{*}{ Technology Self-Efficacy } & No & 96 & 20.10 & 3.01 & .203 & .816 & ----- \\
\hline & Partially & 100 & 20.03 & 2.65 & & & \\
\hline & Yes & 143 & 13.20 & 1.62 & & & \\
\hline \multirow[t]{3}{*}{ Effective Lecture } & No & 96 & 12.80 & 1.55 & 3.229 & .041 & Yes-No- \\
\hline & Partially & 100 & 12.74 & 1.54 & & & Partially \\
\hline & Yes & 143 & 9.65 & 2.67 & & & \\
\hline \multirow{3}{*}{$\begin{array}{l}\text { Self-Efficacy in the Face } \\
\text { of External Factors }\end{array}$} & No & 96 & 10.66 & 2.19 & 5.742 & .004 & Yes-No-Partially \\
\hline & Partially & 100 & 9.74 & 2.18 & & & \\
\hline & Yes & 143 & 97.09 & 15.58 & & & \\
\hline \multirow[t]{3}{*}{$\begin{array}{l}\text { Academic Performance } \\
\text { Total }\end{array}$} & No & 96 & 97.96 & 14.42 & .517 & .597 & ----- \\
\hline & Partially & 100 & 95.88 & 12.81 & & & \\
\hline & Yes & 143 & 14.51 & 6.82 & & & \\
\hline \multirow[t]{2}{*}{ Life Satisfaction Total } & No & 96 & 21.22 & 6.05 & 32.075 & .000 & Yes-No- \\
\hline & Partially & 100 & 17.79 & 6.00 & & & Partially \\
\hline
\end{tabular}


The effect of mobbing on participants' academic performance and life satisfaction was investigated. Participants were divided into 3 groups based on their exposure to mobbing; (1) those who were exposed to mobbing, (2) those who were partially exposed to mobbing and (3) those who were not exposed to mobbing. The results showed a statistically significant difference in academic performance subscale scores and life satisfaction scores between the three groups $(\mathrm{p}<0.05)$.

Table 4. T-Test Results of Provision of Tools and Materials to Academics by Affiliated Institutions

\begin{tabular}{lllllll}
\hline Scales & $\begin{array}{l}\text { Tools and } \\
\text { Materials }\end{array}$ & N & Mean & SD & t & P \\
\hline Foreign Language Self-Efficacy & Yes & 142 & 36.16 & 7.79 & 2.719 & .007 \\
& No & 197 & 33.67 & 9.01 & & \\
Scientific Research Self-Efficacy & Yes & 142 & 19.71 & 3.47 & 2.236 & .026 \\
& No & 197 & 18.81 & 3.79 & & \\
Technology Self-Efficacy & Yes & 142 & 21.08 & 2.54 & 5.126 & .000 \\
& No & 197 & 19.47 & 3.04 & & \\
Effective Lecture & Yes & 142 & 13.14 & 1.44 & 1.870 & .062 \\
& No & 197 & 12.82 & 1.68 & & \\
Self-Efficacy in the Face of External Factors & Yes & 142 & 10.40 & 2.51 & 2.828 & .005 \\
& No & 197 & 9.64 & 2.33 & & \\
Academic Performance Total & Yes & 142 & 100.51 & 13.01 & 3.892 & .000 \\
& No & 197 & 94.44 & 14.95 & & \\
Life Satisfaction Total & Yes & 142 & 19.75 & 7.11 & 5.569 & .000 \\
& No & 197 & 15.67 & 6.29 & & \\
\hline
\end{tabular}

The effect of the provision of tools and materials by the institutions on participants' academic performance and life satisfaction was investigated. The t-test results showed that the provision of tools and materials by the institutions increased participants' academic performance and life satisfaction $(\mathrm{p}<0.05)$.

Table 5. Correlation Analysis between Participants' Life Satisfaction and Academic Performance

\begin{tabular}{|c|c|c|c|c|c|c|c|c|}
\hline & & 1 & 2 & 3 & 4 & 5 & 6 & 7 \\
\hline \multirow{3}{*}{ Foreign Language Self-Efficacy ${ }^{1}$} & $\mathrm{r}$ & 1 & & & & & & \\
\hline & $\mathrm{p}$ & & & & & & & \\
\hline & $\mathrm{n}$ & 339 & & & & & & \\
\hline \multirow{4}{*}{ Scientific Research Self-Efficacy ${ }^{2}$} & $\mathrm{r}$ & $.393^{* *}$ & 1 & & & & & \\
\hline & $\mathrm{p}$ & .000 & & & & & & \\
\hline & $\mathrm{n}$ & 339 & 339 & & & & & \\
\hline & $\mathrm{r}$ & $.516^{* *}$ & $.587^{* *}$ & 1 & & & & \\
\hline \multirow[t]{3}{*}{ Technology Self-Efficacy ${ }^{3}$} & $\mathrm{p}$ & .000 & .000 & & & & & \\
\hline & $\mathrm{n}$ & 339 & 339 & 339 & & & & \\
\hline & $\mathrm{r}$ & $.311^{* *}$ & $.416^{* *}$ & $.571^{* *}$ & 1 & & & \\
\hline \multirow[t]{2}{*}{ Effective Lecture $^{4}$} & $\mathrm{p}$ & .000 & .000 & .000 & & & & \\
\hline & $\mathrm{n}$ & 339 & 339 & 339 & 339 & & & \\
\hline \multirow{3}{*}{$\begin{array}{l}\text { Self-Efficacy in the Face of External } \\
\text { Factors }\end{array}$} & $\mathrm{r}$ & $.250^{* *}$ & $.343^{* *}$ & $.256^{* *}$ & $.189^{* *}$ & 1 & & \\
\hline & $\mathrm{p}$ & .000 & .000 & .000 & .000 & & & \\
\hline & $\mathrm{n}$ & 339 & 339 & 339 & 339 & 339 & & \\
\hline \multirow{3}{*}{ Academic Performance Total ${ }^{6}$} & $\mathrm{r}$ & $.877^{* *}$ & $.712^{* *}$ & $.766^{* *}$ & $.550^{* *}$ & $.478^{* *}$ & 1 & \\
\hline & $\mathrm{p}$ & .000 & .000 & .000 & .000 & .000 & & \\
\hline & $\mathrm{n}$ & 339 & 339 & 339 & 339 & 339 & 339 & \\
\hline \multirow{3}{*}{ Life Satisfaction Total ${ }^{7}$} & $\mathrm{r}$ & .014 & .019 & .074 & -.013 & $.204^{* *}$ & .061 & 1 \\
\hline & $\mathrm{p}$ & .798 & .723 & .176 & .805 & .000 & 262 & \\
\hline & $\mathrm{n}$ & 339 & 339 & 339 & 339 & 339 & 339 & 339 \\
\hline
\end{tabular}


Table 5 shows that there is no correlation between participants' academic performance and life satisfaction, suggesting that high or low life satisfaction does not increase or decrease academic performance and vice versa.

\section{Discussion}

The results indicate that participants have high academic performance. Ergene (2011) also reported a similar result. The results also indicate that participants have high life satisfaction. Çeçen (2008) reported high life satisfaction in university students. Yllmaz \& Altınok (2009) observed that school administrators have high life satisfaction.

The results showed no statistically significant difference in life satisfaction between male and female participants, which was also reported by Ülker Tümlü \& Recepoğlu (2013). Özkara et al. (2015) found no difference in life satisfaction between male and female university students. Telef (2011) reported that there was no difference in life satisfaction between male and female teachers.

However, Yilmaz \& Aslan (2013) reported a significant difference in life satisfaction between male and female teachers. Recepoğlu (2013) found that there was a significant difference in life satisfaction between male and female pre-service teachers while Yilmaz \& Aslan (2013) reported a significant difference in life satisfaction between male and female teachers.

The results showed no correlation between participants' academic performance and life satisfaction, suggesting that high or low life satisfaction does not increase or decrease academic performance and vice versa. Ergene (2011) determined a significant correlation between academic performance and some other variables. However, Impraim (2012) determined that there is no significant correlation between academic performance and the duration of Internet and Facebook use. Köse (2017) found a significant correlation between organizational culture and academic performance. Yilmaz \& Aslan (2013) determined that there is a significant correlation between teachers' life satisfaction and experience of loneliness at work. Recepoğlu (2013) stated that there is a significant correlation between pre-service teachers' life satisfaction and their attitudes towards teaching. Ülker Tümlü \& Recepoğlu(2013) found that there is a significant positive correlation between the life satisfaction and psychological endurance of academic staff. According to Yilmaz \& Aslan (2013), there is a significant negative correlation between teachers' life satisfaction and experience of loneliness at work. Toros (2010) found no relationship between mountaineers' task and ego orientation goals and their life satisfaction.

\section{Conclusion}

This study investigated academics' life satisfaction and academic performance. The analysis showed that the data on academic performance, its subscales and life satisfaction met the normality assumption. In addition, academics' life satisfaction and academic performance levels were found to be high.

The results show that there is a statistically significant difference in academic performance scores between male and female participants, indicating that the former have better academic performance than the latter.

The results also show that there is a statistically significant difference in academic performance scores between participants who were exposed to mobbing and those who were not, indicating that the former are more susceptible to negative attitudes and pressure than the latter. Participants' academic performance and life satisfaction levels differ depending on whether the institutions to which they are affiliated provide them with tools, materials and equipment necessary for both academic and sports purposes. The results indicate that the provision of tools, materials and equipment increases participants' academic performance and life satisfaction.

The results show no relationship between academic performance and life satisfaction, indicating that participants' life satisfaction has no effect on their academic performance and vice versa.

\section{References}

Akın, A., \& Yılmaz, A. (2015). Turkish version of contentment with life scale (clas): the study of validity and reliability. Electronic Journal Of Social Sciences, 14(54), 95-102.

Çeçen, A.R. (2008). Sense of coherence, family sense of coherence and self esteem in predicting life satisfaction among university students. Journal Of Theory And Practice In Education, 4(1), 19-30.

Çetinsaya, G. (2014). Büyüme, kalite, uluslararasılaşma: Türkiye yükseköğretimi için bir yol haritası. Ankara: Yök.

Chow, H. P. H. (2005). Life satisfaction among university students in a Canadian prairie city: a multivariate analysis. 
Social Indicators Research, 70, 139-150. https://doi.org/10.1007/s11205-004-7526-0

Dockery, A. M. (2003). Happiness, life satisfaction and the role of work: evidence from two Australian surveys. Paper presented At 10th National Conference On Unemployment, 10 - 12 December 2003, Newcastle, Uk.

Ergene. T. (2011). The relationships among test anxiety, study habits, achievement, motivation, and academic performance among turkish high school students. Education And Science, 36(160), 320-330.

Güllü, S., \& Çiftçi, E.G. (2016). Examining gym members' perceptions of life quality. International Journal of Social Sciences and Education Research, 2(3), 1251-1265. https://doi.org/10.24289/ijsser.279043

Gür, R. (2017). Development of the academic performance perception scale. Eurasian Journal of Educational Research, 69, 177-197. https://doi.org/10.14689/ejer.2017.69.10

Impraim, S. (2012). The Relationship Among Internet Addiction, Use Of Facebook And Academic Performance. The Institute Of Social Sciences In Partial Fulfillment Of The Requirements For The Degree Of Master Of Arts In Psychology, Fatih University.

Kavak, Y. (2011). Türkiye'de yükseköğretimde büyüme: yakın geçmişe bakış ve uzun vadeli (2010-2050) büyüme projeksiyonları. Yükseköğretim Dergisi, 1(2), 95-102.

Kenan, S. (2015). Modern üniversitenin oluşum süreci. Osmanlı Araştırmalarl, 45, 333-367.

Köse, M.F. (2017). Üniversitelerde Örgüt Kültürü İle Akademik Performans Arasındaki İlişkiler. Doktora Tezi, Gazi Üniversitesi, Eğitim Bilimleri Enstitüsü, Ankara.

Kostak, M.A., Kurt, S., Süt, N., Akarsu, Ö., \& Ergül, G. D. (2014). Healthy lifestyle behaviors of nursing and classroom teaching students. TAF Prev Med Bull, 13(3), 189-196. https://doi.org/10.5455/pmb.1-1362174271

Lavallee, L. F., Hatch, P. M., Michalos, A. C., \& Mckinley, T. (2007). Development of the contentment with life assessment scale (CLAS): Using daily life experiences to verify levels of self-reported life satisfaction. Social Indicators Research, 83, 201-244. https://doi.org/10.1007/s11205-006-9054-6

Okur, M.H. (2007). Yükseköğretim hizmetlerinin pazarlanmasında marka değeri oluşturma ve geliştirme stratejileri: Ankara ilinde örnek bir çalışma. Yüksek Lisans Tezi, Gazi Üniversitesi, Eğitim Bilimleri enstitüsü, Ankara.

Özkara, A.B., Kalkavan, A., \& Çavdar, S. (2015). Examination of the life satisfactions levels of students receiving education in sports sciences. International Journal Of Science Culture And Sport (Intjscs), Special Issue, 336-346.

Recepoğlu, E. (2013). Analyzing the relationship between prospective teachers' life satisfaction and attitudes concerning teaching profession. H. U. Journal Of Education, Özel Sayl(1), 311-326.

Sousa, L., \& Lyubomırsky, S. (2001). Life Satisfaction. In J. Worell (Ed.), Encylopedia Of Women And Gender: Sex Similarities And Differences And The Impact Of Society On Gender. San Diego: Ca academic press.

Telef, B, B. (2011). The study of teachers' self-efficacy, job satisfaction, life satisfaction and burnout. Elementary Education Online, 10(1), 91-10.

Toros. T., Akyüz, U., Bayansalduz, M., \& Soyer, F. (2010). Görev ve ego yönelimli hedeflerin yaşam doyumu ile ilişskisinin incelenmesi (dağcılık sporu yapanlarla ilgili bir çalışma. Uluslararası İnsan Bilimleri Dergisi, 7(2), 1039-1050.

Ülker Tümlü, G., \& Recepoğlu, E. (2013). The relationship between psychological resilience and life satisfaction of university academic staff. Journal Of Higher Education And Science, 3(3), 205-2013.

Vara, S. (1999). Yoğun bakım hemşirelerinde iş doyumu ve genel yaşam doyumu arasındaki ilişkinin incelenmesi. Yüksek Lisans Tezi, Ege Üniversitesi, Sağlık Bilimleri Enstitüsü, İzmir.

Veenhoven, R. (1996). The study of life satisfaction. In W. E. Sarıs, R. Veenhoven, A. C. Scherpenzeel \& B. A Bunting(eds.), Comparative study Of Satisfaction with Life In Europ, Eötvös university Pres İçinde, 11-48.

Yılmaz, E., \& Altınok, V. (2009). Okul yöneticilerinin yalnızlık ve yaşam doyum düzeylerinin incelenmesi. Educational Administration: Theory And Practice, 15(59), 451-469.

Yllmaz, E., \& Aslan, H. (2013). Examination of relationship between teachers' loneliness at workplace and their life satisfaction. Pegem Journal Of Education \& Instruction, 3(3), 59-69. https://doi.org/10.14527/C3S3M6 